\title{
A Contrastive Analysis of Interpersonal Function Between the Chinese and English Versions of The Sight of Father's Back
}

\author{
Lijun $\mathrm{Xin}^{1} \&$ Jun Gao ${ }^{1}$ \\ ${ }^{1}$ College of Foreign Languages, University of Shanghai for Science and Technology, Shanghai, China \\ Correspondence: Lijun Xin, College of Foreign Languages, University of Shanghai for Science and Technology, \\ 314 Jungong Road., Shanghai 200093, China. E-mail: 1154134625@qq.com
}

Received: April 9, 2020 Accepted: May 12, 2020 Online Published: May 27, 2020

doi:10.5539/ells.v10n2p85 URL: https://doi.org/10.5539/ells.v10n2p85

This research is sponsored by National Social Science Foundation, China. No.19BYY110.

\begin{abstract}
As a reminiscent prose, The Sight of Father's Back was written by the modern writer, Zhu Ziqing, in 1925. A wave of warm current floods a large body of readers since this essay describes, in earnest, love of father. This research performs a contrastive analysis of interpersonal function between the Chinese and English versions of The Sight of Father's Back in terms of mood, modality, and evaluation meanings. We find that mood and evaluation meanings display parallel distribution. Declarative and exclamatory moods occur most frequently in both the Chinese and English versions, whereas interrogative mood is at a premium. Besides, various evaluative adjectives and adverbs are used in both versions. However, modality shows remarkable discrepancies. The English version tends to adopt modal verbs with median-and-low value, while most median-and-high value modal verbs are presented in the Chinese version. In our view, the exercise of median-and-high value modal verbs reflects the thoughts more directly. While the selection of median-and-low value modal verbs might be concerned with the need for politeness. Besides, diverse choices of modal verbs are incident to various modal meanings along with research purposes.
\end{abstract}

Keywords: contrastive analysis, evaluation meaning, interpersonal function, The Sight of Father's Back

\section{Introduction}

In recent years, spotlights in discourse analysis have fallen upon the exercise of Halliday's interpersonal function. For instance, Liang (2020) employed it to construe identification construction within narratives. Zhang et al. (2015) made a parse of a novel concerning this function and Ma et al. (2017) analyzed the utterance in the court trial through the same lens. Besides, Wang et al.(2017) explored the tense in the abstracts of the academic papers through the same prism. Furthermore, Weng and Zhang (2019) elaborated the translation of the adverb in the corpus. It can be demonstrated that this function is inclusive, blanketing the diagnosis of various styles in more ways than one. However, there is a deficit of research in contrastive studies between English and Chinese texts. In this regard, this research will draw a contrastive construal between the Chinese and English versions of The Sight of Father's Back, heading for preparing the ground for the contrastive analysis in interpersonal function.

\section{Research Questions}

In this research, we reckon that different realizations will be exercised through the prism of the interpersonal function between the Chinese and English versions. We hypothesize that different languages may bring different performances dealing with the same function. The reasons behind the realizations might be traced back to language ontology.

This research is to contrast various distributions surrounding this function between the Chinese and English versions. To this end, it attempts to address the following questions: What are the similarities and differences, between the Chinese and English versions in terms of mood, modality, and evaluation meanings?

\section{Literature Review}

Grounded on China Academic Journal Network, we search The Sight of father's Back as the key word over the last two decades and classify them into two research areas. One sets forth from the source language, and the 
other touches upon the target language. Properly speaking, a diet of investigations takes the teaching of Chinese texts as a starting point, while some studies zero in on reinterpretation of the tenor. It should be noticed that only two papers delve into the target language. They are either to compare the parallels and departures between the source language and target language or to scope the aesthetic value of the translated version. Through combing the literature review out, it is identified that the research fails in contrastive analysis. In this sense, this study blazes the trail for probing the interpersonal function.

Interpersonal function, in functional grammar, interprets identification, station, posture, and so forth, of the speaker, displaying prevision and assessment through the agency of language, which can also bear on others. In this regard, it is the span between interpersonal interactions. Besides, it is illustrated, in gross, in mood, modality and evaluation meanings, revealing the relationship between the speaker and the listener. There are two main types of moods, i.e., indicative and imperative moods. The indicative can be assorted into declarative and interrogative moods. Modality also describes the modes of thinking. In terms of modality values, they are summarized into three sorts, i.e., high-value modal verbs, such as "must, ought to, need, have to, dare"; median-value modal verbs, for instance, "will, would, shall, should, be to"; low-value modal verbs, for example, "may, might, can, could" (Halliday, 2004).

Martin and White (2005) argue that the appraisal system better uncovers the author's position. Besides, the appraisal theory zeroes in on a specific evaluation stance through the prism of the author or the one carrying out comments, who negotiates these postures along with the actual or potential respondent. In their terms, this system is of appraisal, blanketing attitudes, the strength of emotion, and all sorts of manners to arrest readers. Appraisal meaning can be performed through phonological, lexical, and grammatical prisms (Dai \& Hu, 2008). This research will analyze appraisal meaning in terms of lexis mostly reflected in adjectives and adverbs.

\section{Methodology}

\subsection{Research Data}

In this research, the data adopted are anchored to The Sight of Father's Back between its Chinese version by Zhu Ziqing and its English version translated by Zhang Peiji. As a roaring success, this essay painted an earnest picture of a father-and-son relationship. It was written in the bleak situation where grandmother died and father was with unemployment. In this sense, the father had to borrow money for the funeral service. After finishing the funeral, the son was to attend university in Beijing. As one of the modern prose of memory lane, this essay delineated in no small part that after he sent his son to the Pukou depot, the father bought his son some oranges. Looking at his father's back, the writer was struck by his father's devoted love. Through the prism of ordinary trifles, the son carved out an extraordinary topic, which is instructional to us. The exercise of simple but clinical words bulks large in depicting the father's altruistic love for his son.

\subsection{Research Procedure}

The procedure are as follows. To begin with, we sifted the expressions performing the interpersonal function, and wrote them down. Then we calculated the mood, modality, and evaluation meanings, meantime, their occurrence percentage. Furthermore, the reasons of these distributions are presented.

\section{Results and Data Interpretation}

\subsection{Analysis of Interpersonal Function in Its Chinese Discourse}

\subsubsection{Mood Analysis}

As an essential section in building and maintaining interpersonal interaction, the mood is embodied in declarative, exclamatory, imperative, and interrogative sentences.

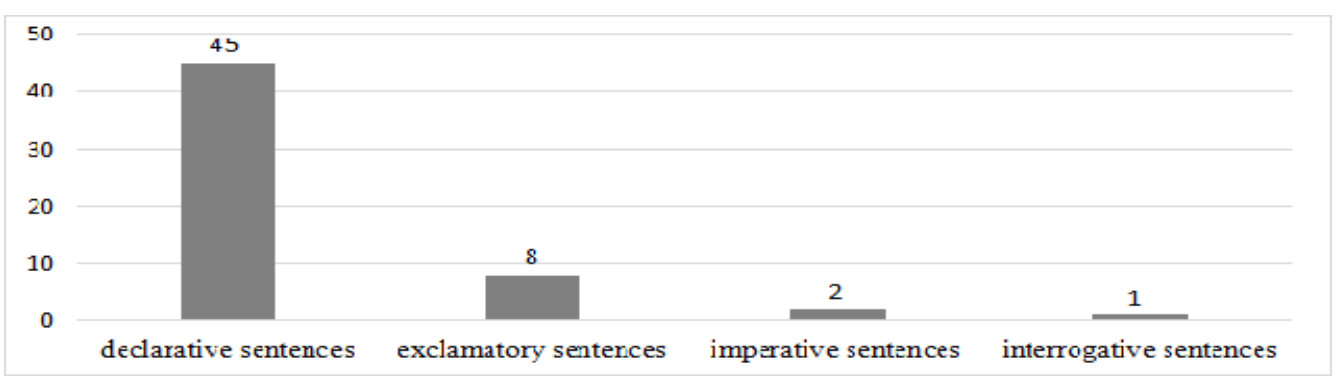

Figure 1. Distribution of mood in its Chinese discourse 
Figure 1 shows that the Chinese version has 56 instances indicating mood. Declarative sentences make up the highest footprint $(80.36 \%)$ with 45 cases, followed by exclamatory sentences $(14.28 \%)$ with 8 instances; Besides, there are 2 imperative sentences, accounting for $3.57 \%$, followed by one interrogative sentence (1.79\%). Therefore, being the prevailing sentence patterns in the Chinese version, declarative and exclamatory sentences blanket $94.64 \%(80.36+14.28)$.

(1) ài! wŏ bù-zhī hé-shí zài néng yŭ tā xiāng-jiàn! (“唉!我不知何时再能与他相见!”) (Zhang, 2007, p. 49)

In severe straits, father often tempered tantrum. After separation, the son went to Beijing. Despite their breakup, he felt uneasy every night. Besides, father also got remarried, forcing mother and sister to leave. We argue that the father, who was tainted in the decayed feudal system, carried on the obstinate tradition, which was a can of worms. While his son was in the grip of new thoughts, upholding equality and mutual respect. Just as someone put it, a cat may look at a king. Such opinions carried great weight then. Under this firework, the feudal autocracy, in turn, rocked. But the remained obstinate thoughts put a crimp in father's mind. It could be indicated, that there were some departures between father and son, leaving them into silent hatred.

Two years later, the son received a letter from his father in which he mentioned that he slipped and was not feeling well. At the sight of it, the son could not help weeping. The scene emerged again, especially many years ago, his father helped him to buy oranges in the station as father hobbled towards the railway track. The picture, the sight of father's back in particular, as though echoed. The son, at that moment, was on the cusp of qualm. He was losing sleep over his father's health. What are the reasons behind the conversion? It entails the awakening in consciousness of the son. He realized that life was the most precious thing. The son felt guilty of not realizing this point earlier. Furthermore, he might appreciate it that he finally awakened. Realizing the value of life, he would cherish it as a new lease of life. Therefore, tapping into exclamatory mood is to lay stress on the son's sadness and his internal mixed feelings, such as guilt, regret, treasure, and gratitude. At this moment, the son showed great concern for his father. Once father was the one he could count on, and now the son desired to be father's umbrella, protecting him from the rain or the scorching sun.

(2) ěr-qiě wŏ zhè-yàng-dà nián-ji de rén, nán-dào hái bù-néng liào-lǐ zì-jǐ ma? (“而且我这样大年纪的人, 难道 还不能料理自己吗?”) (Zhang, 2007, p. 48)

After the father sent his son to the train, he told the son to be careful. Lingering over whether it was reasonable to ask the waiter to look after his son, the experienced father resolved to do so. While the son thought it was too impractical because the waiter in his eyes only admitted money. And the son felt that he was an adult and could look after himself. In his mind, the father's deed was superfluous and would not be useful. Father, however, insisted on asking a stranger to take care of his son even if he knew it effortless. The sole reason ought to be his love and concern (Liu, 2018). Employing interrogative mood was to express that the son was opinionated. He kept self-righteous, not realizing the good intentions of the father, which revealed, in profile, that the son was still young and immature, suffering delusions of grandeur.

\subsubsection{Modality Analysis}

Modality reflects the speaker's views and postures. Halliday divided modality into high, median, and low values. It is pointed out that the explicit modal meaning depends on the high-and-low value modal verbs. The attitude and politeness of the speaker are expressed in the number of modal verbs (Halliday, 2004).

Table 1. Distribution of modality in its Chinese discourse

\begin{tabular}{llllll}
\hline modal verbs & bì (必) & yào (要) & xū (须) & děi (得) & kě (可) \\
\hline value & high & median & high & high & high \\
number & 1 & 6 & 3 & 1 & 1 \\
\hline
\end{tabular}

Table 1 reflects that the Chinese version employs liberal amounts of modal verbs with high-and-median value to depict father, which is representative of information focus. Besides, it aligns with the purpose of this essay. The author drew acres of ink to portrait father. Meanwhile, it indicates the following status difference between the father and the son. Being dominant, the father boasts upper status and thus holds sway over his son.

\subsubsection{Analysis of Evaluation Meaning}

The Chinese text employed various evaluative adjectives and adverbs, especially in the description of the bleak situation, such as “huò-bù-dān-xíng-de (“祸不单行的”), măn-yuàn-láng-jí-de (“满院狼藉的”), bù-jīn (“不禁”), sù-sù-de (“籁籁地”), căn-dàn (“惨淡”). It can be found that these words are negative, stretching out bleak and 
desolate feelings. It reflects, in this regard, the son's grief to the sudden decease of grandmother, indicating his devoted love for grandmother; While it, in profile, hints at a bad patch they were striking. At that moment they were in poor circumstances, which was a sharp contrast to the easy circumstances they had before. When characterizing the back of father, the son adopted pán-shān-de, màn-màn, bù-róng-yì, nŭ-lì-de, hěn-qīng-sōng, zhōng-yú (“蹒跚地、慢慢、不容易、努力的、很轻松、终于”), painting a pitiful picture of father's fumbling action On his way back, father puffed the soil on his clothes and dissembled free and easy. The expression, hěn-qīng-sōng (“很轻松”), impressed us pictorially. He was not prepared to put his son under concern, to that end, he deliberately appeared to be effortless. All the abundant use of the wording was an interpretation of the father's strenuous posture, sublimating the subject.

\subsection{Analysis of Interpersonal Function in Its English Version}

\subsubsection{Mood Analysis}

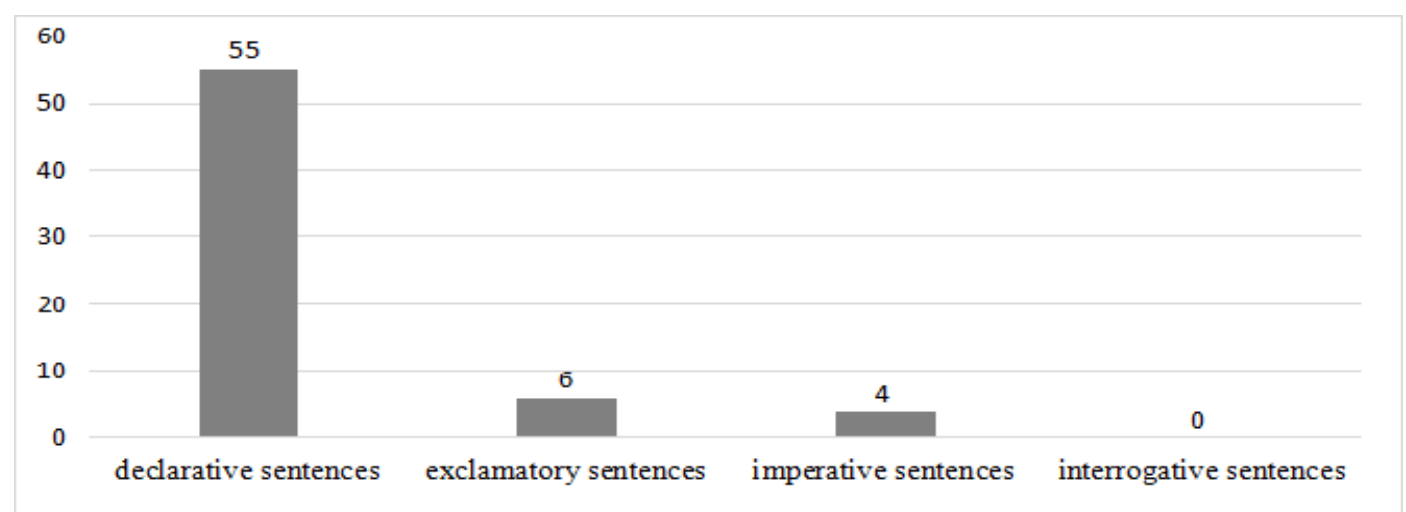

Figure 2. Distribution of mood in the English version

Figure 2 shows that the English version has 65 instances of embodying mood. Among the four sorts of realizations of mood, declarative sentences are the dominant patterns, accounting for $84.62 \%$ involving 55 instances, followed by exclamatory sentences $(9.23 \%)$ with 6 instances. Besides, there are 4 imperative sentences, accounting for $6.15 \%$. It should be noticed that there is no interrogative sentence. Declarative and exclamatory sentences are thus the prevailing patterns in its English discourse, constituting $93.85 \%(84.62+$ 9.23) of the total.

(3) "After some wavering, he finally decided that he himself would accompany me to the station." (Zhang, 2007, p. 50)

In this instance, the son was to attend university in Beijing. At first, the father intended to ask the waiter from the hotel to look after his son. However, he finally determined to send his son to the depot by himself. This sentence used declarative mood to describe the father's worries and concerns over his son. Though 20 years old, the son was still his beloved one. Father was not adept at words, he was effusive in caring for his son through the lens of action. As the proverb goes, action speaks louder than words. Here the description of his psychological traits paints a picture of a devoted father. Thence, the employment of declarative mood reflects the deep love of a father.

(4) “Don't move around." (Zhang, 2007, p. 51)

After he sent his son to the depot, the father was going to buy the son some oranges. It was in this situation that the father told his son these words. The son was to go with his father, but the father did not allow. As the depot was mobbed, the father let his son leave there to find out him easily. Besides, father knew it was a little tough, but it was worth the hassle for his son. The fact was that to buy oranges, he had to cross the tracks, jump down and climb up, which was quite difficult for an ordinary person, not to mention a stout man like the father. The use of the imperative mood was intended to describe, through the prism of action, a father's concern, and deep love. The tide of opinion had turned on that father was the person unheeded. As if his presence was to protect us without the spotlight, however, he should be the one on the radar screen. 


\subsubsection{Modality Analysis}

Table 2. Distribution of modality in the English version

\begin{tabular}{lllllll}
\hline modal verbs & must & would & won't & can & might & should \\
\hline value & high & median & median & low & low & median \\
number & 1 & 4 & 1 & 1 & 1 & 1 \\
\hline
\end{tabular}

Table 2 interprets that acres of modal verbs in median-and-low value are exercised in the English version, and only one high-value modal verb is employed. The recipes, for the above outcome, are as follows. It can be reader-arrested, capturing readers at close quarters through employing the modal verbs with median-and-low value. If reversed, the tone will be strong and tough through the exercise of high-value modal verbs. Then the status between the author and readers is different, leaving a long distance. The author, thence, will be in the saddle. The Chinese discourse, however, widely employ high-value modal verbs.

\subsubsection{Analysis of Evaluation Meaning}

The English version also adopted a chunk of evaluative adjectives and adverbs. When characterizing that they were down on their luck, the writer employed "singly" with a negative adverb "never" in a polar manner. This implied that the disaster, to add insult to injury, was in more ways than one. Temporarily, it was extremely inaccessible to take on this resignation. But things had come to a pass, it was no use being distressed. Hence, as a father, he had to refresh himself. He knew that everything cut both ways and dark days would be dispersed. When he exhorted his son to restrain his grief, father used the adverb "fortunately" to show his rosy outlook towards hard knocks, indicating that he was positive. Translating anguish to the dynamo, they would appreciate up-and-coming stars. Thus, there is always one way at the end of the path. Furthermore, this expression is also an approach to soothe his son that when thrown lemons into life, they can make them into lemonade.

\section{Major Findings and Discussion}

\subsection{Major Findings of the Research}

This paper made a contrastive analysis of interpersonal function between the Chinese and English versions of The Sight of Father's Back. The primary conclusions wound up.

It can be found that the Chinese and English versions share similar features concerning mood. Declarative and exclamatory moods are most frequently distributed in both the English and Chinese versions whereas interrogative mood is at a premium. In terms of modality, both versions are exercises of median value modal verbs. As for evaluation meaning, we can wind up that diverse evaluative adjectives and adverbs occur most frequently in both English and Chinese versions.

Modality is in stark contrast. To sum up, modal verbs with median-and-low value are typically adopted in its English version, while its Chinese version tends to employ modal verbs with median-and-high value.

\subsection{Discussion}

Concerning mood, as can be observed, declarative and exclamatory sentences are employed more frequently. It seems to us that the grounds are twofold. Stylistically, essay grows out of three branches, embracing narrative, emotional, and philosophical discourse. Traced back to the discourse selected, it can be seen that it is a narrative's oyster interacting with lyricism. Furthermore, concerning the content, this essay, to a great degree, makes a point of describing and evincing affection. In this sense, both versions adopt a boatload of evaluative adverbs and adjectives. Previous research also supported our assumptions. According to Li (2018), declarative sentences are mainly used to provide information. The extensive exercises of declarative and exclamatory sentences are reasonable, and rightly so.

In terms of the original assumptions, we can find that different languages give rise to various devices in performing the interpersonal function. These devices, in turn, carry weight in interpreting the function. Different modes of thinking opt for the adoption of various language forms. In terms of modality, the English version tends to employ modal verbs with median-and-low value. However, the Chinese version widely adopt median-and-high value modal verbs. Why would these departures present? This paper argues that it can be traced back to the ontology of English and Chinese languages. Ren and Wang (2017) find that English texts always adopt median-and-low value modal verbs, while Chinese discourse tends to employ modal verbs with median-and-high value. This signal, in our viewpoints, that the exercise of median-and-high modal verbs reflects the thoughts more directly. While the selection of employing median-and-low modal verbs might be concerned 
with the need for politeness. Besides, diverse choices of modal verbs are incident to various modal meanings along with research purposes.

\section{Conclusion}

This research multiplies the contrastive analysis, providing a reference for the contrastive study of interpersonal function. We found that mood and evaluation meanings presented parallel distributions. Modality, however, showed sharp differences. Behind them lay multiple modes of thinking. Plugging into them will enhance our outlooks and cognition between source and target discourse, carrying weight in both interaction and cognition indicated by the authors. Still, the materials selected are mono discourse, it is therefore a preliminary study. For further study, we recommend to adopt the same style in a sweeping fashion, or anchoring to a tapestry of styles with various recipes.

\section{References}

Dai, H. H., \& Hu, H. F. (2008). The Analysis of Interpersonal Function on Early Autumn written by Lanston Hughes. Jiangxi Social Sciences, 12, 203-206.

Halliday, M. A. K. (2004). An Introduction to Functional Grammar (3rd ed.). London: Edward Arnold.

Li, F. H. (2018). The Interpersonal Significance of 2018 New Year Speech by President Xi Jinping. Youth Journalist, 21, 31-32.

Liang, H. Y. (2020). Identity Construction in Narratives Under Multiple Meta-functions. Foreign Language Education, 41(01), 17-21.

Liu, H. (2018). The Ground of Cognitive Pragmatics in Critical Reading-Based on The Sight of Father's Back. Language Planning, 09, 8-12, 36.

Ma, Z. J., Liu, J., \& Chen, H. Q. (2017). Prosodic Feature and Realization of Interpersonal Function of Modal Verbs in Court Discourse. Contemporary Rhetoric, 06, 33-41.

Martin, J. R., \& White, P. (2005). The Language of Evaluation: Appraisal in English. New York: Palgrave macmillan Ltd. https://doi.org/10.1057/9780230511910

Ren, K., \& Wang, Z. H. (2017). A Contrastive Study of Modality Based on Systemic Functional Linguistics-Taking Political News for Example. Contemporary Foreign Language Studies, 02, 20-26, 45, $109-110$.

Wang, Q. Z., Liu, W. J., \& Li, X. (2017). A Study of Interpersonal Function on Abstracts in Academic Papers. Foreign Language Education, 38(05), 18-22.

Weng, Y. M., \& Zhang, L. Y. (2019). An Exploration of the Modal Adverb "běn-lái” (“本来”) in Corpus Based on Interpersonal Function. Foreign Language and Literature, 35(02), 118-125.

Xu, T. Q. (1999). A Study of Chinese Features and Language Commonness. Linguistic Researches, 04, 1-13.

Zhang, J., Tan, L., \& Ling, Z. Q. (2015). An Analysis of Interpersonal Function on Adverbs and Theme Construction in The Cement Garden. Journal of Tianjin University (Social Sciences), 17(04), 361-365.

Zhang, P. J. (2007). Selected Modern Chinese Essays 1 Rendered into English. Shanghai: Shanghai Foreign Language Education Press.

\section{Copyrights}

Copyright for this article is retained by the author, with first publication rights granted to the journal.

This is an open-access article distributed under the terms and conditions of the Creative Commons Attribution license (http://creativecommons.org/licenses/by/4.0/). 